\title{
Procedures adopted by orthodontists for space closure and anchorage control
}

André da Costa Monini1, Luiz Gonzaga Gandini Júnior², Ary dos Santos-Pinto²,

Luiz Guilherme Martins Maia ${ }^{1}$, Willian Caetano Rodrigues ${ }^{3}$

Objective: The aim of this study was to identify the procedures adopted by Brazilian orthodontists in the following situations: extraction space closure, anchorage control in case of necessary anchorage for group A and frequency of skeletal anchorage use, especially in the upper jaw. Method: A questionnaire was sent to the e-mail address of all dentists registered in the Brazilian Federal Council of Dentistry. Results: The results showed that most Brazilian orthodontists usually perform extraction space closure by means of sliding mechanics. The use of palatal bar, inclusion of second molars in the archwire and space closure performed in two phases are the most used techniques for anchorage control in the upper jaw. The skeletal anchorage is referenced by $36.5 \%$ of specialists as a routine practice for the upper jaw anchorage. Conclusions: There is a wide variety of procedures adopted by Brazilian orthodontists for orthodontic space closure and anchorage control.

Keywords: Orthodontic anchorage procedures. Orthodontic space closure. Questionnaires.

Objetivo: esse trabalho tem o objetivo de identificar as condutas adotadas pelos ortodontistas brasileiros para o fechamento ortodôntico de espaços de extrações, controle de ancoragem em caso de necessidade de ancoragem do grupo A, e frequência de uso de ancoragem esquelética nesses casos, especialmente na arcada superior. Métodos: um questionário foi enviado para o endereço eletrônico de todos os ortodontistas inscritos no Conselho Federal de Odontologia. Resultados: os resultados mostraram que a maioria dos ortodontistas brasileiros usualmente faz fechamento de espaço de extrações com mecânicas de deslizamento. O uso de barra palatina, incorporação de segundos molares no arco e fechamento de espaço em duas fases são as condutas mais utilizadas para controle de ancoragem na arcada superior. A ancoragem esquelética é referenciada por 36,5\% dos especialistas como forma rotineira de ancoragem na arcada superior. Conclusões: existe uma grande variedade de condutas adotas por ortodontistas brasileiros tanto para o fechamento ortodôntico de espaço quanto para o controle de ancoragem em casos de maior necessidade de retração anterior.

Palavras-chave: Procedimentos de ancoragem ortodôntica. Fechamento de espaço ortodôntico. Questionários.

${ }^{1} \mathrm{PhD}$ in Orthodontics, FOAr-UNESP.

${ }^{2}$ Full professor in Orthodontics, FOAr-UNESP.

${ }^{3} \mathrm{MSc}$ in Laser in Dentistry, USP.
How to cite this article: Monini AC, Gandini Júnior LG, Santos-Pinto A, Maia LGM, Rodrigues WC. Procedures adopted by orthodontists for space closure and anchorage control. Dental Press J Orthod. 2013 Nov-Dec;18(6):86-92.

Submitted: August 29, 2011 - Revised and accepted: March 24, 2012

"The authors report no commercial, proprietary or financial interest in the products or companies described in this article.

Contact address: Luiz Gonzaga Gandini Júnior

Av. Casemiro Perez, 560 - Vila Harmonia - Araraquara/SP - Brazil CEP: $14.802-600$

E-mail: luizgandini@uol.com.br 


\section{INTRODUCTION}

Since the introduction of dental extractions as a treatment resource, many space closure and anchorage control procedures have been developed. Space closure mechanics can be classified into two forms: with or without friction. Friction mechanics is that in which the teeth slide on the archwire or the archwire slides on the brackets, whereas in frictionless mechanics the teeth are moved by loop action. Anchorage is classified in accordance with the differential space closure required between anterior and posterior teeth. ${ }^{2}$ Group A anchorage is that in which posterior segments must remain in their original position and space is fully closed by anterior retraction. Group B anchorage requires that approximately half of the space be used for retraction. Group $\mathrm{C}$ anchorage requires that nearly the entire space be closed by protraction of the posterior teeth.

Studies assessing clinical procedures for space closure and anchorage control are not common, ${ }^{10}$ especially in Brazil. Assessing the procedures employed by Brazilian practitioners may be beneficial for clinicians who can compare their own practice with those presented by the researches and re-evaluate them in future studies. Furthermore, it is a way of identifying the most common clinical practices and those that are in disuse, in addition to the professional training received, which can result in changes in personal practice.

Thus, this paper aims at identifying the procedures adopted by Brazilian orthodontists for extraction space closure, anchorage control in case of necessary anchorage for Group A and frequency of skeletal anchorage use in these cases, especially in the upper jaw.

\section{MATERIAL AND METHODS}

On October 23 $3^{\text {rd }}, 2008$, the Brazilian Federal Council of Dentistry (FCD) had 10,121 orthodontists duly registered, 7,572 of which were registered as specialists in Orthodontics and Facial Orthopedics and 2,549 in Orthodontics. There were 5,423 electronic mails registered. A questionnaire (Fig. 1) was sent to these e-mails with objective and discursive questions about their practice regarding anchorage control and space closure. Out of the total number of electronic addresses, 1,464 were not active and 337 were repeated. Thus, 3,650 electronic mails were actually sent.
The questionnaire comprised six questions, two of which were objective while four were discursive. Question 1 asked about the space closure technique most commonly adopted by the practitioner in his office routine. Question 2 asked about the resources used by them for anchorage control in the upper jaw, in cases of maximum control, with no restrictions on the conduct adopted. Questions 3.1 and 3.2 were about professional conduct for space closure and anchorage control in a case

Figure 1 - Questionnaire used in the research.

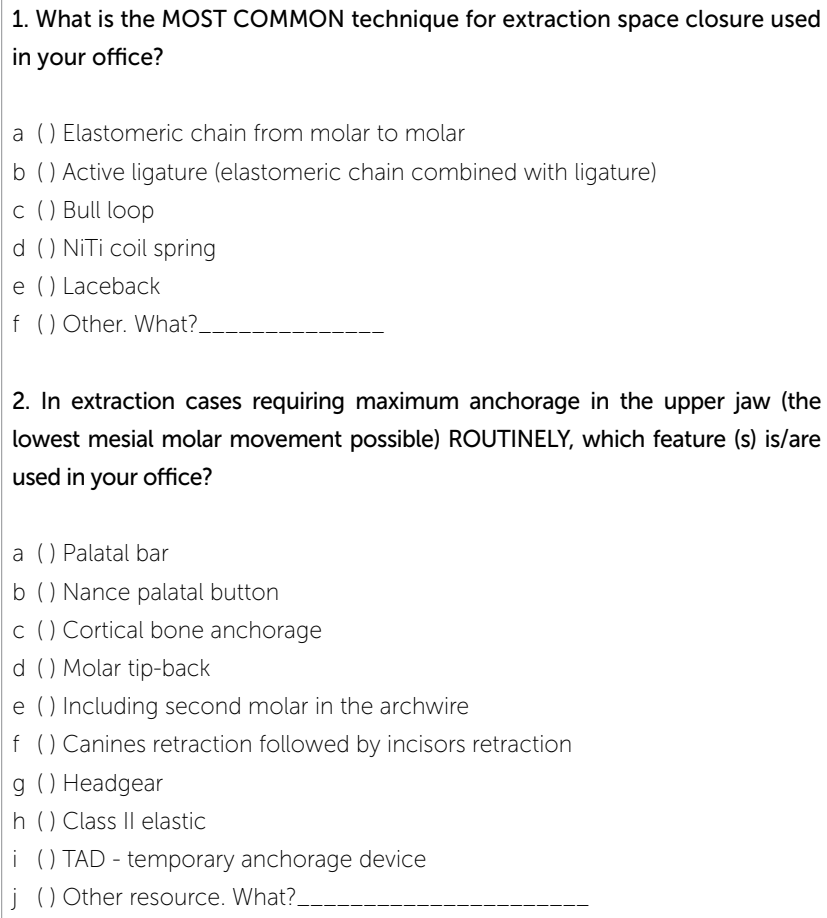

3. Consider the following case: adult patient with complete bilateral Class II. The proposed treatment included extraction of two upper first premolars and retraction of anterior teeth. The patient WILL NOT USE EXTRAORAL APPLIANCE NEITHER MINI-SCREW. In your office, in this situation:

3.1 - How is extraction space closure performed?

3.2 - How is anchorage control performed?

4. Consider the following case: adult patient with class I. The proposed treatment included extractions of four first premolars with maximum retraction of anterior teeth. The patient WILL NOT USE EXTRAORAL APPLIANCE NEITHER MINI-SCREW. In your office, in this situation:

4.1 - How is extraction space closure performed?

4.2 - How is anchorage control performed? 
requiring greater control in the upper posterior anchorage, in an adult patient with restrictions on the use of headgear (HG) and mini-screws. Questions 4.1 and 4.2 were about professional conduct for space closure and anchorage control in a case requiring greater control of posterior anchorage in both arches, in an adult patient with restrictions on the use of HG and mini-screws.

The data obtained in the questionnaires were computerized by means of a database created by a Microsoft Excel 2007 spreadsheet. The same software was used to survey the frequency of responses. The results were analyzed by descriptive statistics.

\section{RESULTS}

A total of 597 (16.38\%) e-mails were sent back. Taking into account the total number of members enrolled in the Brazilian Federal Council of Dentistry, the percentage of response was $5.90 \%$.

The responses were tabulated according to the number of answers the professional chose. Thus, score 1 corresponded to one answer; score 2 represented two answers and score 3 corresponded to three alternatives and so on.

The results of Question 1 are shown in Table 1. They demonstrate that $63.81 \%$ use sliding mechanics (friction) while $36.18 \%$ use mechanical attraction (frictionless) for space closure. 19.26\% of the specialists indicated more than one answer to this question.

As for Question 2, when asked about the resources used for anchorage control in the upper jaw, the two most frequent responses were the use of palatal bar (403) and the inclusion of the second molar in the arch (328) (Table 2). Approximately 36.5\% of the respondents claimed to routinely use skeletal anchorage devices in cases of maximum anchorage in the upper jaw.

Table 3 shows the results of Questions 3.1 and 4.1 regarding the space closure technique used in hypothetical cases of Class II and I in Group A anchorage.

Tables 4 and 5 show the results regarding the specialist's conduct of anchorage control in case of hypothetical treatment of Class II and I malocclusion, respectively,

Table 1 - Absolute frequency of responses to Question 1.

\begin{tabular}{|c|c|c|c|c|c|c|c|c|c|c|}
\hline Responses & $\begin{array}{l}\text { Active } \\
\text { ligature }\end{array}$ & $\begin{array}{c}\text { Elastomeric } \\
\text { chain }\end{array}$ & $\begin{array}{l}\text { Bull } \\
\text { loop }\end{array}$ & $\begin{array}{l}\text { Niti Coil } \\
\text { Spring }\end{array}$ & Laceback & T loop & $\begin{array}{l}\text { DKL } \\
\text { loop }\end{array}$ & $\begin{array}{l}\text { Ricketts } \\
\text { loops }\end{array}$ & $\begin{array}{l}\text { Other } \\
\text { resource }\end{array}$ & $n$ \\
\hline 1 & 141 & 75 & 116 & 29 & 28 & 19 & 23 & 21 & 34 & 482 \\
\hline 2 & 50 & 26 & 29 & 32 & 23 & 7 & 7 & 1 & 3 & 88 \\
\hline 3 & 11 & 9 & 15 & 14 & 9 & 6 & 3 & 0 & 2 & 23 \\
\hline 4 & 3 & 2 & 2 & 4 & 4 & 1 & 0 & 0 & 0 & 4 \\
\hline Total & 205 & 112 & 162 & 79 & 64 & 33 & 33 & 22 & 39 & \\
\hline
\end{tabular}

$n=$ number os specialists. The values of the answers correspond to the number of options given by the same professional.

Table 2 - Absolute frequency of responses to Question 2

\begin{tabular}{|c|c|c|c|c|c|c|c|c|c|c|c|c|c|c|}
\hline Responses & $\begin{array}{c}\text { Palatal } \\
\text { bar }\end{array}$ & $\begin{array}{l}\text { Nance } \\
\text { palatal } \\
\text { button }\end{array}$ & $\begin{array}{c}\text { Cortical } \\
\text { bone } \\
\text { anchorage }\end{array}$ & Tip-back & $\begin{array}{l}\text { Second } \\
\text { molar }\end{array}$ & $\begin{array}{l}\text { Two- } \\
\text { phase } \\
\text { retraction }\end{array}$ & HG & $\begin{array}{c}\text { Intermaxillary } \\
\text { elastic }\end{array}$ & TAD & MPD & $\begin{array}{c}\text { Differential } \\
\text { moments }\end{array}$ & $\begin{array}{l}\text { Tip-edge } \\
\text { brackets }\end{array}$ & Other & $n$ \\
\hline 1 & 19 & 9 & 7 & 0 & 4 & 5 & 9 & 0 & 38 & 1 & 0 & 0 & 0 & 92 \\
\hline 2 & 54 & 33 & 5 & 2 & 23 & 17 & 16 & 11 & 18 & 0 & 0 & 0 & 2 & 90 \\
\hline 3 & 86 & 45 & 6 & 8 & 59 & 60 & 35 & 28 & 30 & 3 & 2 & 2 & 2 & 121 \\
\hline 4 & 95 & 53 & 8 & 12 & 82 & 76 & 62 & 52 & 44 & 0 & 5 & 3 & 3 & 123 \\
\hline 5 & 76 & 40 & 11 & 15 & 82 & 72 & 52 & 51 & 43 & 2 & 1 & 0 & 3 & 89 \\
\hline 6 & 54 & 33 & 13 & 16 & 60 & 57 & 49 & 47 & 30 & 0 & 0 & 1 & 3 & 60 \\
\hline 7 & 17 & 12 & 5 & 10 & 16 & 16 & 15 & 16 & 13 & 0 & 0 & 0 & 1 & 17 \\
\hline 8 & 2 & 2 & 1 & 2 & 2 & 2 & 1 & 2 & 2 & 0 & 0 & 0 & 0 & 2 \\
\hline $\begin{array}{l}\text { No } \\
\text { response }\end{array}$ & 0 & 0 & 0 & 0 & 0 & 0 & 0 & 0 & 0 & 0 & 0 & 0 & 0 & 3 \\
\hline Total & 403 & 227 & 56 & 65 & 328 & 305 & 239 & 207 & 218 & 6 & 8 & 6 & 14 & \\
\hline
\end{tabular}

Second molar = second molar must be included in the arch as an anchorage element; two-phase retraction = canine retraction followed by incisors retraction; $\mathrm{HG}=$ headgear; TAD = Temporary Skeletal Anchorage Devices; MPD = Mandibular propulsion devices; $N=$ number of specialists 
in Group A anchorage. The two most frequent responses in both malocclusions are the use of palatal bar and space closure initially performed with canine retraction, followed by incisors retraction.

\section{DISCUSSION}

This research was carried out by means of electronic mail, with $16.38 \%$ of response rate. International studies using questionnaires report a response rate of about $50 \%$ with questionnaires being applied to patients. ${ }^{15}$ Some studies carried out in Brazil with questionnaires being applied to professionals presented similar rates in comparison to the present research., ${ }^{4,6,14}$ Studies involving a sample of orthodontists presented a response rate of $6 \% 0^{3}$ to $7.7 \% . .^{10}$ Our results had the response rate doubled in comparison to the studies aforementioned.

Table 3 - Absolute (n) and relative (\%) frequency of responses to questions 3.1 and 4.1

\begin{tabular}{|c|c|c|c|c|c|c|c|c|c|}
\hline Malocclusion & $\begin{array}{l}\text { Bull loop } \\
\text { n (\%) }\end{array}$ & $\begin{array}{c}\text { DKLV loop } \\
\text { n } \\
(\%)\end{array}$ & $\begin{array}{c}\text { Ricketts } \\
\text { loops } \\
\text { n (\%) }\end{array}$ & $\begin{array}{c}\text { Segmented } \\
\text { T-Loop } \\
\text { n (\%) }\end{array}$ & $\begin{array}{l}\text { Continuous } \\
\begin{array}{c}\text { T-Loop } \\
\text { n (\%) }\end{array}\end{array}$ & $\begin{array}{c}\text { Others loops } \\
\text { n (\%) }\end{array}$ & $\begin{array}{c}\text { Stiding } \\
\text { mechanics } \\
\text { n (\%) }\end{array}$ & $\begin{array}{l}\text { Sliding to the } \\
\text { canine and } \\
\text { loop to the } \\
\text { incisors n (\%) }\end{array}$ & $\begin{array}{c}\text { No response } \\
\mathbf{n}(\%)\end{array}$ \\
\hline Class II & $60(10.05)$ & $27(4.52)$ & 24 (4.02) & $26(4.36)$ & $17(2.85)$ & $54(9.05)$ & 215 (36.01) & 79 (13.23) & 95 (15.91) \\
\hline Class I & $42(7.04)$ & $34(5.70)$ & 19 (3.18) & $16(2.68)$ & $9(1.51)$ & $45(7.54)$ & 223 (37.35) & $82(13.74)$ & $127(21.27)$ \\
\hline
\end{tabular}

Table 4 - Frequency of responses to Question 3.2

\begin{tabular}{|c|c|c|c|c|c|c|c|c|c|c|c|c|c|c|}
\hline Class II & $\begin{array}{l}\text { Retrac- } \\
\text { tion in } 1 \\
\text { phase }\end{array}$ & $\begin{array}{l}\text { Two- } \\
\text { phase } \\
\text { retraction }\end{array}$ & $\begin{array}{c}\text { Palatal } \\
\text { Bar }\end{array}$ & $\begin{array}{l}\text { Lip } \\
\text { bum- } \\
\text { per }\end{array}$ & $\begin{array}{l}\text { Nance } \\
\text { palatal } \\
\text { button }\end{array}$ & $\begin{array}{l}\text { Second } \\
\text { molar }\end{array}$ & $\begin{array}{l}\text { Tip- } \\
\text { back }\end{array}$ & $\begin{array}{l}\text { Intermaxil- } \\
\text { lary elastic }\end{array}$ & MPD & $\begin{array}{c}\text { Cortical } \\
\text { bone } \\
\text { anchorage }\end{array}$ & $\begin{array}{l}\text { Lin- } \\
\text { gual } \\
\text { arch }\end{array}$ & $\begin{array}{l}\text { Differential } \\
\text { moments }\end{array}$ & Other & n \\
\hline 1 response & 14 & 5 & 41 & 0 & 9 & 3 & 1 & 9 & 4 & 0 & 0 & 2 & 0 & 72 \\
\hline 2 responses & 14 & 64 & 108 & 0 & 29 & 40 & 3 & 63 & 5 & 2 & 0 & 4 & 1 & 160 \\
\hline 3 responses & 9 & 148 & 150 & 0 & 78 & 94 & 9 & 103 & 2 & 7 & 3 & 7 & 6 & 201 \\
\hline 4 responses & 1 & 97 & 98 & 0 & 57 & 88 & 12 & 78 & 1 & 4 & 4 & 0 & 4 & 111 \\
\hline 5 responses & 1 & 33 & 31 & 1 & 22 & 33 & 9 & 31 & 0 & 5 & 2 & 2 & 0 & 34 \\
\hline 6 responses & 0 & 2 & 2 & 0 & 2 & 2 & 1 & 1 & 0 & 2 & 0 & 0 & 0 & 2 \\
\hline 7 responses & 0 & 1 & 1 & 0 & 0 & 1 & 1 & 1 & 0 & 0 & 0 & 1 & 1 & 1 \\
\hline $\begin{array}{l}\text { No } \\
\text { response }\end{array}$ & 0 & 0 & 0 & 0 & 0 & 0 & 0 & 0 & 0 & 0 & 0 & 0 & 0 & 16 \\
\hline Total & 39 & 350 & 431 & 1 & 197 & 261 & 36 & 286 & 12 & 20 & 9 & 16 & 12 & \\
\hline
\end{tabular}

Retraction in 1 phase = retraction of incisors and canines in one step; retraction in 2 phases = retraction of the canines and posterior retraction of the incisors; second molar = inclusion of second molar in the archwire as an anchor; MPD = Mandibular propulsion device, $\mathrm{N}=$ number of specialists.

Table 5 - Frequency of responses to Question 4.2

\begin{tabular}{|c|c|c|c|c|c|c|c|c|c|c|c|c|c|c|}
\hline Class II & $\begin{array}{c}\text { Retraction } \\
\text { in } 1 \\
\text { phase }\end{array}$ & $\begin{array}{c}\text { Retrac- } \\
\text { tion in } 2 \\
\text { phases }\end{array}$ & $\begin{array}{c}\text { Palatal } \\
\text { Bar }\end{array}$ & $\begin{array}{l}\text { Lip } \\
\text { bum- } \\
\text { per }\end{array}$ & $\begin{array}{l}\text { Nance } \\
\text { palatal } \\
\text { button }\end{array}$ & $\begin{array}{l}\text { Second } \\
\text { molar }\end{array}$ & $\begin{array}{l}\text { Tip- } \\
\text { back }\end{array}$ & $\begin{array}{l}\text { Intermaxil- } \\
\text { lary elastic }\end{array}$ & MPD & $\begin{array}{c}\text { Cortical } \\
\text { bone } \\
\text { anchorage }\end{array}$ & $\begin{array}{l}\text { Lin- } \\
\text { gual } \\
\text { arch }\end{array}$ & $\begin{array}{l}\text { Differential } \\
\text { moments }\end{array}$ & Other & $n$ \\
\hline 1 response & 11 & 5 & 30 & 0 & 4 & 9 & 2 & 5 & 1 & 1 & 1 & 5 & 2 & 65 \\
\hline 2 responses & 21 & 25 & 81 & 6 & 28 & 38 & 9 & 11 & 0 & 3 & 33 & 4 & 4 & 121 \\
\hline 3 responses & 9 & 96 & 116 & 13 & 44 & 67 & 13 & 33 & 0 & 14 & 66 & 5 & 12 & 159 \\
\hline 4 responses & 4 & 120 & 119 & 14 & 68 & 84 & 14 & 47 & 0 & 11 & 89 & 4 & 20 & 146 \\
\hline 5 responses & 0 & 47 & 46 & 6 & 24 & 44 & 17 & 24 & 0 & 6 & 27 & 3 & 7 & 50 \\
\hline 6 responses & 0 & 15 & 14 & 2 & 13 & 15 & 5 & 9 & 0 & 4 & 9 & 1 & 5 & 15 \\
\hline 7 responses & 0 & 4 & 4 & 2 & 1 & 4 & 2 & 4 & 0 & 1 & 4 & 1 & 1 & 4 \\
\hline $\begin{array}{l}\text { No } \\
\text { response }\end{array}$ & 4 & 0 & 0 & 0 & 0 & 0 & 0 & 0 & 0 & 0 & 0 & 0 & 0 & 37 \\
\hline Total & 49 & 312 & 410 & 43 & 182 & 261 & 62 & 133 & 1 & 40 & 229 & 23 & 51 & \\
\hline
\end{tabular}

Retraction in 1 phase = retraction of incisors and canines in one step; retraction in 2 phases = retraction of the canines and posterior retraction of the incisors second molar = inclusion of second molar in the archwire as an anchor; MPD = Mandibular propulsion device, $\mathrm{N}=$ number of specialists. 
The interest and/or knowledge about the subject involved in the research could have influenced the response rates. ${ }^{4,9}$ Presenting a short questionnaire was of paramount importance to increase the response rate. ${ }^{15}$ Despite the fact that the questionnaire applied in this research comprised six questions, only, the presence of four open questions may have influenced the response rates. The results showed that the majority of specialists (63.81\%) prefer the technique based on friction mechanics for orthodontic space closure. Moreover, active ligature and elastomeric chain proved to be the most used resources in this technique (Table 1). Space closure is the most significant change occurring during the transition period from standard edgewise to preadjusted appliance systems. ${ }^{13}$ The preadjusted brackets allowed the use of different techniques for sliding mechanics and the results proved this technique to be highly accepted, when applied. The results of this research are lower than the ones yielded by a British study, in which loops were practically not used for space closure and the sliding technique was used at a rate of $98 \% .{ }^{1}$

With regard to Question 2, which questioned about the resources used for anchorage control in the upper jaw, the use of palatal bar and inclusion of the second molar in the archwire were the most cited answers (Table 2). Although it has been widely used for anchorage, the palatal bar does not significantly improve molar mesialization control in extraction cases. , $^{5,11,12,16,18}$ A longitudinal study concerning the techniques used by American orthodontists showed a decrease in the use of palatal bars. In 2008, only $20 \%$ of those who answered the questionnaire stated the use of that device. ${ }^{10}$ Likewise, a British study showed a percentage of $24.6 \% .{ }^{1}$ Even though it is not possible to assert that the device has not been widely used due to being ineffective for anchorage control, that is probably the reason. Nearly half of the specialists $(40.8 \%)$ combine at least 3 or 4 different techniques for anchorage control in the upper jaw, which means they chose 3 or 4 answers to the same question. As for this question, the specialists could choose skeletal and headgear anchorage techniques. More than 35\% (36.5\%) of the experts claimed to use the skeletal anchorage technique on a daily basis for group A anchorage in the upper jaw. Previous studies revealed that $20.3 \% 0^{3}$ to $39.3 \%{ }^{10}$ of interviewed orthodontists claim that they have never used mini-screws. These researches are used as reference, but cannot be compared to the present study because the latter used the skeletal anchorage technique for anchorage control in space closure while the oth$\mathrm{ers}^{3,10}$ have considered all clinical cases. One of these researches ${ }^{9}$ showed that using skeletal anchorage for anchorage control is the second technique orthodontists recommend the most, while molar mesialization is the first. However, another study demonstrated that molar intrusion followed by Class II malocclusion treatment are the main indications for the use of mini-screws. ${ }^{10}$ Additionally, it is worth noting that the skeletal anchorage technique is used by Brazilian orthodontists more than it is used by the British. Only $0.2 \%{ }^{1}$ have claimed to use that technique. However, we must bear in mind that this British study was conducted 2 years before the current study.

Questions 3.1 and 4.1 questioned about extraction space closure techniques in cases of Class I and II in which anchorage is strictly necessary (Table $3)$. The percentage regarding the use of the sliding technique was 36\% and $37.3 \%$ in Class II and I, respectively. These results decrease when compared to the results of the first question (63.81\%). Apparently, specialists take special care with the cases that have been presented in comparison to common cases. Unfortunately, a high percentage of specialists did not clearly state the answer for these questions, which may result in biased interpretation. With regard to anchorage control, no studies suggesting that retraction performed by means of frictionless mechanics is superior to friction mechanics have been carried out. It has been widely accepted that the use of loops allows clinicians to calibrate forces and moment ratios employed during retraction. However, although this situation is extremely advantageous since it provides knowledge of the force systems involved in the mechanics used, there is no scientific evidence of it being associated with a better anchorage control. A few studies have compared both mechanics, however, they do not allow anchorage loss between both space closure techniques to be assessed, since patients used headgear or were submitted to skeletal anchorage. In other words, the arch sides were not independent from each other, thus, not allowing assessment on the response of the space closure mechanics technique used. ${ }^{7,19}$ 
Conducts concerning the high need of posterior anchorage control in Class I and II malocclusions are the subject of Questions 3.2 and 4.2 (Tables 4 and 5). When the answers to these questions are compared, nearly $40 \%$ of the experts are worried about the use of palatal arch as an anchorage device used for Class I cases, and even more specialists try to avoid the use of intermaxillary elastics. The most common answers with regard to both malocclusions were the use of palatal bar and space closure performed by means of canine retraction at early stages, followed by incisor retraction. To date, two studies aimed at assessing the difference in anchorage loss between space closure performed with unique retraction (one phase) and retraction in two phases (canine retraction followed by incisors retraction). ${ }^{8,17}$ The results of both studies showed no significant difference between these different treatment approaches. There is no support in the literature that states the use of two retractions aiming at preserving anchorage. It is probable that such technique is recommended for cases in which partial canine retraction creates spaces for alignment of incisors, in cases of crowding. ${ }^{17}$
Our study reflects the challenges inherent to research-based practice. These include not only difficulty in recruiting patients who may not be motivated to participate in research, but also self-selection of orthodontists who are eager to participate, both of which can lead to biased findings. ${ }^{1,9}$

\section{CONCLUSIONS}

The present study demonstrated that:

" The sliding technique is more commonly prescribed by specialists for extraction space closure;

"When specialists are free to choose the technique that is going to be used for anchorage control, they usually perform control based on the use palatal bar with incorporation of second molars. Additionally, when the use of headgear and skeletal anchorage is not possible, the palatal bar and the two-phase space closure technique are the conducts mostly prescribed;

" Skeletal anchorage is used by $36.5 \%$ of specialists as an ordinary technique for anchorage control in the upper arch. Nearly $40 \%$ of specialists use lingual arch for anchorage control in the lower arch in Class I cases when skeletal anchorage is impossible. 


\section{REFERENCES}

1. Banks P, Elton $V$, Jones $Y$, Rice P, Derwent $S$, Odondi $L$. The use of fixed appliances in the UK: a survey of specialist orthodontists. J Orthod. 2010;37(1):43-55

2. Burstone $\mathrm{CJ}$. The segmented arch approach to space closure. Am J Orthod. 1982:82(5):361-78.

3. Buschang PH, Carrillo R, Ozenbaugh B, Rossouw PE. 2008 survey of AAO members on miniscrew usage. J Clin Orthod. 2008;42(9):513-8.

4. Cimardi ACBS, Fernandes APS. Câncer bucal: a prática e a realidade clínica dos cirurgiões-dentistas de Santa Catarina. RFO. 2009:14(2):99-104.

5. Feldmann I, Bondemark L. Anchorage capacity of osseointegrated and conventional anchorage systems: a randomized controlled trial. Am J Orthod Dentofacial Orthop. 2008;133(3):339 e19-28.

6. Glasberg J, Horiuti L, Novais MAB, Canavezzi AZ, Miranda VDC, Chicoli FA, et al. Prevalence of the Burnout syndrome among Brazilian medical oncologists. Rev Assoc Med Bras. 2007:53(1):85-9

7. Hayashi K, Ueshi J, Murata M, Mizogushi I. Comparison of maxillary canine retraction with sliding mechanics and a retraction spring: a three dimensional analysis based on a midpalatal orthodontic implant. Eur J Orthod. 2004:26(6):585-9.

8. Heo W, Nahm DS, Baek SH. En masse retraction and two-step retraction of maxillary anterior teeth in adult Class I women. A comparison of anchorage loss. Angle Orthod. 2007:77(6):973-8.

9. Hyde JD, King GJ, Greenlee GM, Spiekerman C, Huang GJ. Survey of orthodontists' attitudes and experiences regarding miniscrew implants. J Clin Orthod. 2010:44(8):481-6

10. Keim RG, Gottlieb EL, Nelson AH, Vogels DS 3rd. 2008 JCO study of orthodontic diagnosis and treatment procedures, part 1: results and trends. J Clin Orthod. 2008;42(11):625-40
11. Kojima $Y$, Fukui $H$. Effects of transpalatal arch on molar movement produced by mesial force: a finite element simulation. Am J Orthod Dentofacial Orthop. 2008:134(3):335 e331-7; discussion 335-6.

12. Liu YH, Ding WH, Liu J, Li Q. Comparison of the differences in cephalometric parameters after active orthodontic treatment applying mini-screw implants or transpalatal arches in adult patients with bialveolar dental protrusion. J Oral Rehabil. 2009:36(9):687-95.

13. McLaughlin RP, Bennett JC. The transition from standard edgewise to preadjusted appliance systems. J Clin Orthod. 1989:23(3):142-53.

14. Moana Filho EJ. Levantamento das atitudes e crenças dos ortodontistas com relação à disfunção têmporo-mandibular e dor orofacial. Rev Dental Press Ortod Ortop Facial. 2005;10(4):60-75.

15. Nakash RA, Hutton JL, Jorstad-Stein EC, Gates S, Lamb SE. Maximizing response to postal questionnaires: a systematic review of randomized trials in health research. BMC Med Res Method. 2006:6:5

16. Stivaros N, Lowe C, Dandy N, Doherty B, Mandall NA. A randomized clinical trial to compare the Goshgarian and Nance palatal arch. Eur J Orthod. 2010:32(2):171-6

17. Xu TM, Zhang X, Oh HS, Boyd RL, Korn EL, Baumrind S. Randomized clinical trial comparing control of maxillary anchorage with 2 retraction techniques. Am J Orthod Dentofacial Orthop. 2010:138(5):544.e541-9: discussion 544-5.

18. Zablocki HL, MCNamara Jr JA, Franchi L, Baccetti T. Effect of the transpalatal arch during extraction treatment. Am J Orthod Dentofacial Orthop. 2008;133(6):852-60

19. Ziegler $P$, Ingervall B. A clinical study of maxillary canine retraction with a retraction spring and with sliding mechanics. Am J Orthod Dentofac Orthop. 1989:95(2):99-106 